\title{
Possibilities of the electrochemical drilling process's (ECM) vibroacoustic analysis
}

\author{
Adam Troszyński ${ }^{1, *}$, and Michat Liss ${ }^{1}$ \\ ${ }^{1}$ University of Technology and Life Sciences, Faculty of Mechanical Engineering, \\ Al. Prof. S. Kaliskiego 7, 85-796 Bydgoszcz, Poland
}

\begin{abstract}
Summary. In the course of metals treatment, there occurs a direct interaction of a tool with the processed material. It is connected with occurrence of different physio-mechanical processes significantly influencing the material's properties, among the others such as the surface's roughness. An attempt to estimate the shaped material's surface in the course of the ECM process based on the measurements of the high-potential plate's oscillations, is presented in the article.
\end{abstract}

\section{Introduction}

Coming in of many constructional materials of special properties among which we may single out tool steels, self-bonded carbides, composite materials and titanium alloys, is the result of dynamic development of the material engineering. Newly developed materials are more and more often used on responsible constructional elements, as they are characterized by good mechanical properties, among the others by big hardness, high resistance to abrasion and corrosion. A common feature characterizing the above listed materials is their exceptionally difficult workability [1].

Electrochemical machining ECM is one of the processing methods used for shaping elements made of constructional materials irrespective of their mechanical properties. Thanks to these properties, it is widely used among the others in the engine industry, aeronautical industry, as well as in biology, chemistry, electronics and medicine $[2,3,4]$.

The quality of the conducted electrochemical machining (ECM) is most often assessed based on the shaped sample's surface, verification of which can be realized only following completion of the whole process, conducting the roughness ' measurement. No possibilities to monitor of the machining ECM process in the course of its performance, results in generation of losses in the situation, when the machining process brings no desired effect, in the form of for ex.: expected roughness of the shaped good's surface.

This article presents the attempt to assess the quality of the electrochemical drilling process ECM, one of the more important parameter of which is the obtained shaped surface's roughness . So, an attempt was made to connect the characteristic parameters of vibrations' signals obtained from a high-potential electrode with roughness of a shaped sample's surface.

\section{Electrocheical machining ECM}

Contactless electrochemical machining also called profiling, is one of many popular methods of a surface's shaping. Removal of the surface material's layer requires connecting of a positive electric current source's pole to a machined object (PO), while to a high-potential electrode (ER) of a negative electric current's pole. The interelectrode space is powered with electrolyte, thanks to what there take place processes of an electric charge's exchange, the consequence of what is dissolution of a machined object giving it a shape of a defined precision. In the interelectrode slot we deal with the mixture of electrolyte, hydrogen particles

\footnotetext{
* Corresponding author: adatro000@utp.edu.pl
} 
and products formed as a result of electrochemical dissolution, which significantly decide on the ECM machining precision $[5,6]$.

The fact, that the precision of the machined surface is the higher the smaller is the distance between the high-potential plate (ER) and the machined object (PO) is a particular feature in the electrochemical machining ECM. In case of precise machining, applying of the interelectrode slots' thicknesses below $0,1-0,05 \mathrm{~mm}$ is necessary.

Such a small a slot's thickness presents a problem with running a stable drilling ECM process. It is caused by many factors, among the others by liberation of gas phase in electrolyte, heating up of electrolyte by the flow of electric current through a center, and low electrolyte's flow speed. The above listed factors make the intensive removal of dissolution products and heat from the interelectrode space impossible to a considerable degree. It increases the risk of occurrence of the critical ECM state and electrical discharges damaging the high-potential plate and a machined object [7].

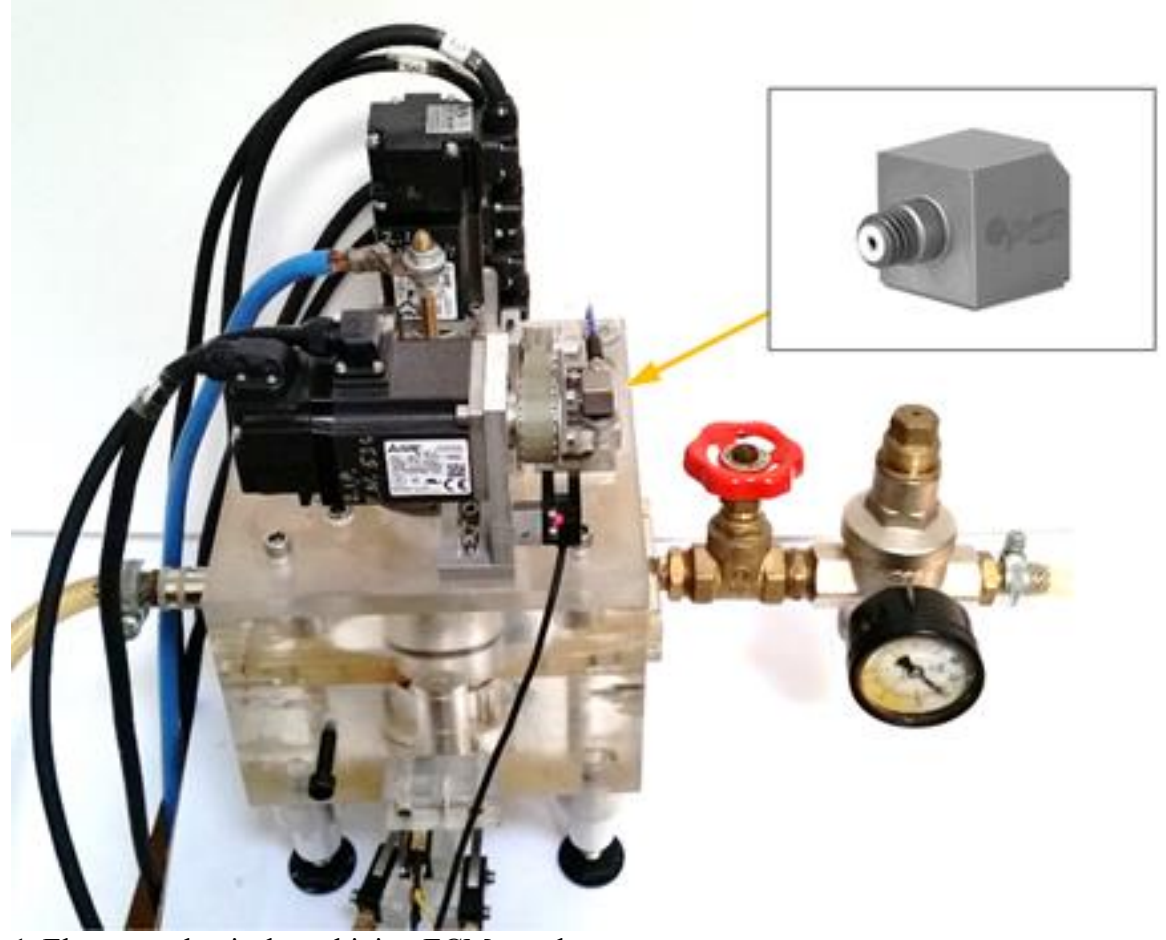

Fig. 1. Electromechanical machining ECM stand.

The electrochemical drilling machining was conducted at the following input parameters:

- interelectrode voltage $\mathrm{U}$

- original slot $\mathrm{h}$

- feed motion speed PO

- electrolyte temperature

- electrolyte type

- machining time

- stream of the electrolyte Q volume

- frequency of transverse vibrations

- transverse vibrations' amplitude
$-14 \mathrm{~V}$,

$-0,1 \mathrm{~mm}$,

$-0,1 \mathrm{~mm} \cdot \mathrm{mm}^{-1}$,

$-293 \mathrm{~K}$,

$-\mathrm{NaNO}_{3}$ 15\%,

$-300 \mathrm{~s}$,

$-0,004 \mathrm{~m}^{3} \cdot \mathrm{mm}^{-1}$,

$-10 \mathrm{~Hz}$,

$-0,2 \mathrm{~mm}$.

Application of a complex movement of a high-potential plate in the feed plane is one of many methods enabling operation at very small interelectrode slots. Periodically changing the thickness of the interelectrode slot makes it possible to correct the machining precision 
at a minimum slot, while in case of maximum slot - good electrolyte's exchange. Appropriately selected kinematics of a high-potential plate's movement as well as frequency of its vibrations, influences the machine surface's precision [8].

The studies were conducted on 10 samples having the diameter $35 \mathrm{~mm}$ made of tool steel NC6 in an improved condition having the hardness 55 HRC. In figure 2-a there is presented a sample prior to drilling, while in figure 2-b a sample following its electrochemical drilling.

a)

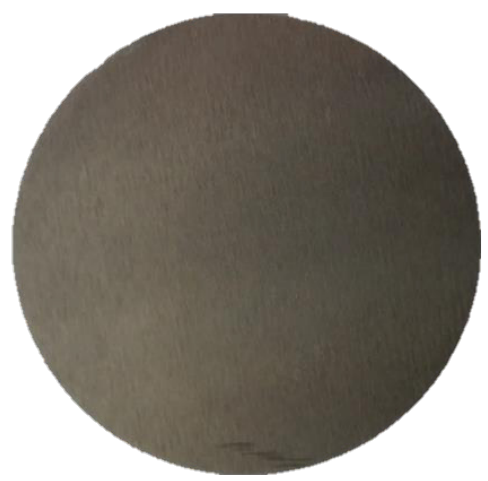

b)

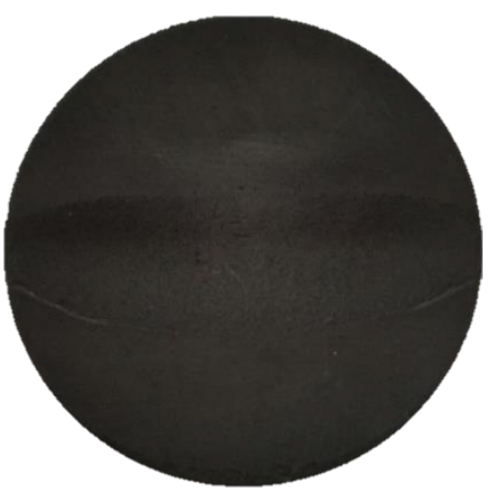

Fig. 2. A sample used in ECM tests: a) a sample prior to its ECM machining ECM, b) sample after its ECM machining.

\section{Vibroacoustic analysis in the course of the ECM machining}

Apart from application of the impulse current, introduction of a high-potential plate's vibration is one of the methods increasing the machining's precision. The periodically changing thickness of an interelectrode slot, makes it possible to use smaller thicknesses of an interelectrode slot as compared to machining without vibrations, as the periodically occurring bigger thicknesses of the interelectrode slot create good conditions of an electrolyte's exchange and carrying the dissolution products off. From the analysis of the literature it results, that introduction of a high-potential plate's vibrations increases the machining precision and its reliability $[9,10,11]$ and in case of high vibrations' frequencies, the dynamic effects occurring in the interelectrode slot become important. So, monitoring of vibroacoustic parameters of high-potential plate occurring during material's processing process is necessary.

In the conducted studies, the forced vibrations of a high-potential plate were registered in one axis with the use of piezoelectric sensor of PCB Piezoelectronics. The observed frequencies' band was determined as 100 [Hz]. According to the Shanon theory, there was assumed the sampling frequency amounting to $200[\mathrm{~Hz}]$. Modulations of the registered vibration' signal most often result from operation of servomotors causing the electrode's movement and the flow of the electrolytic agent, what has been determined by conducting appropriate analysis of the amplitude-frequency characteristics. However, an appropriately selected sensor and the place of its assembly contributed to the fact, that these phenomena did not significantly influence the form of the determined characteristics FFT.

Analysis of the electrochemical drilling process' vibration spectra came down to finding the frequency of the high-potential plate's forcing together with subsequent harmonious ones and observing the values of the vibrations' amplitude (in the form of acceleration $\left[\mathrm{m} / \mathrm{s}^{2}\right]$ ). The selected amplitude-frequency characteristics is presented in figure 3 . 


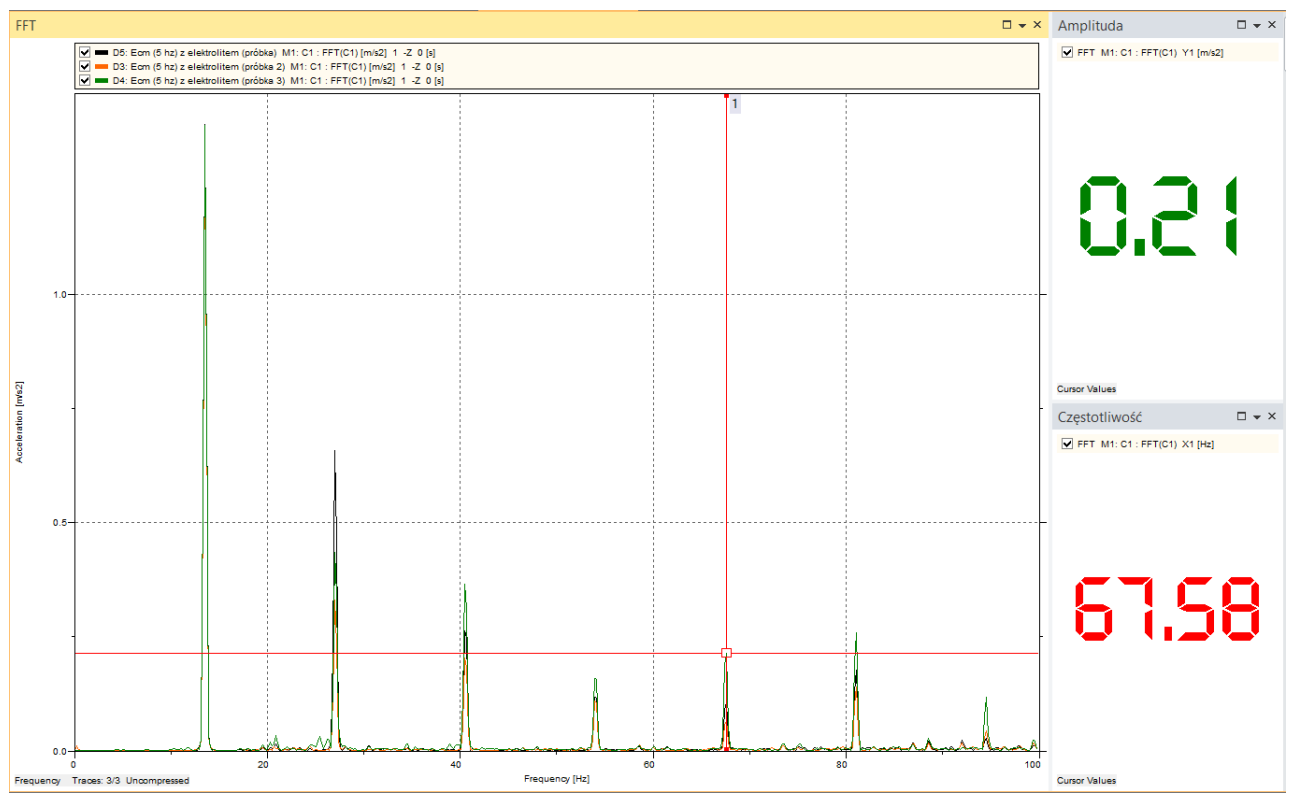

Fig. 3. Spectrum FFT together with a cursor enabling the preview of the amplitude's values and vibrations' frequency.

Dynamic identification of the ECM process was conducted also based on the analysis of the registered time courses. The selected time courses are presented in figure 4.

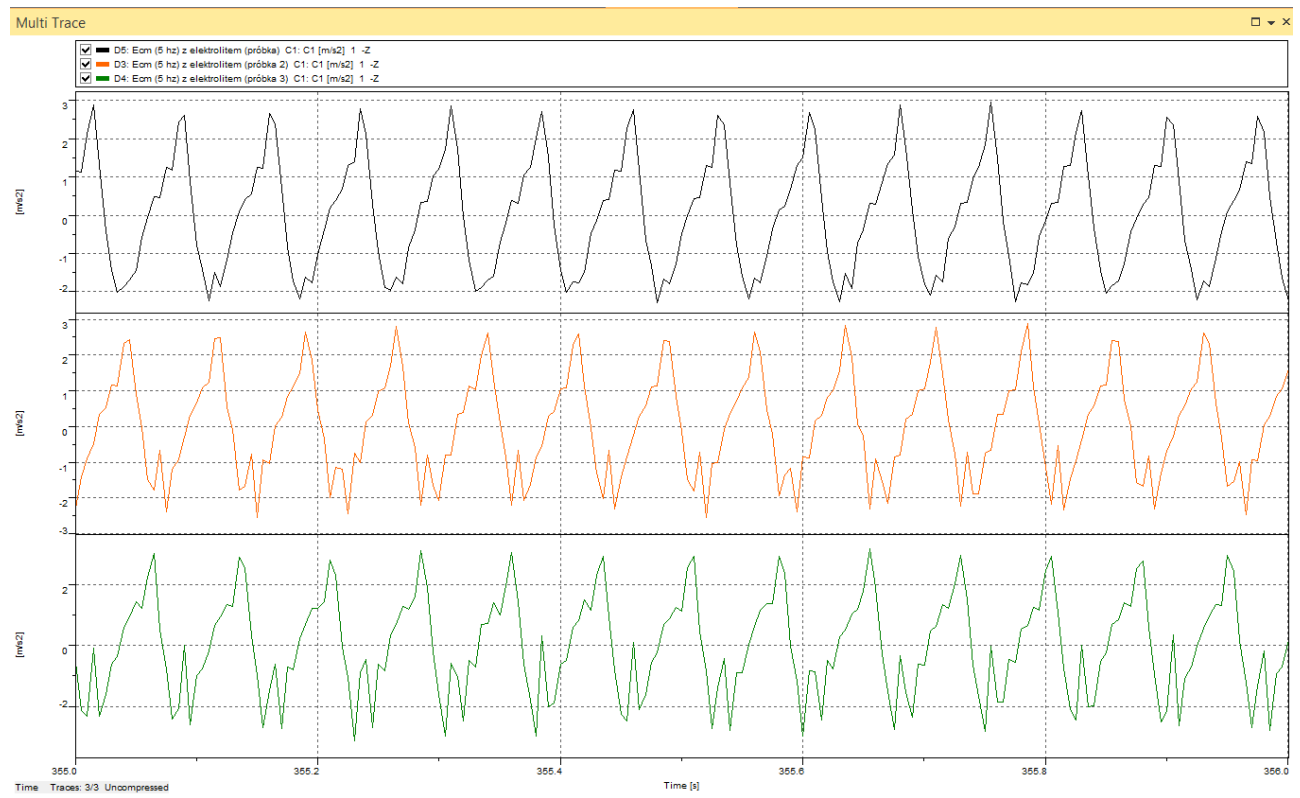

Fig. 4. Selected section of time courses registered during the electrochemical drilling process ECM.

\section{Assessment of the surface after the ECM process}

The surface obtained after the electrochemical drilling, was inspected with respect to the surface roughness. The Ra parameters were used to assess the tested samples, which are the mean arithmetic deviation of the roughness' profile, with the use of which we obtain information on quality of the machined surface. Measurement of the tested surface was 
performed on the surface roughness meter make Mahr, in accordance with the direction presented in the figure (fig. 5).

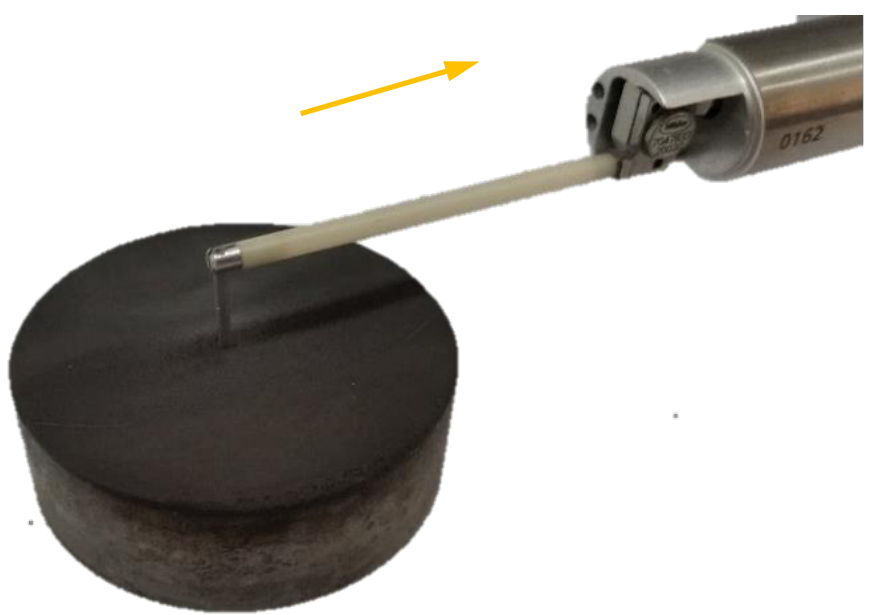

Fig. 5. Measurement of roughness following the ECM machining.

Roughness of the studied samples was measured in three places in order to check the roughness' distribution along the whole sample's surface. Figure 6 presents the places in which the above- mentioned measurement was conducted.

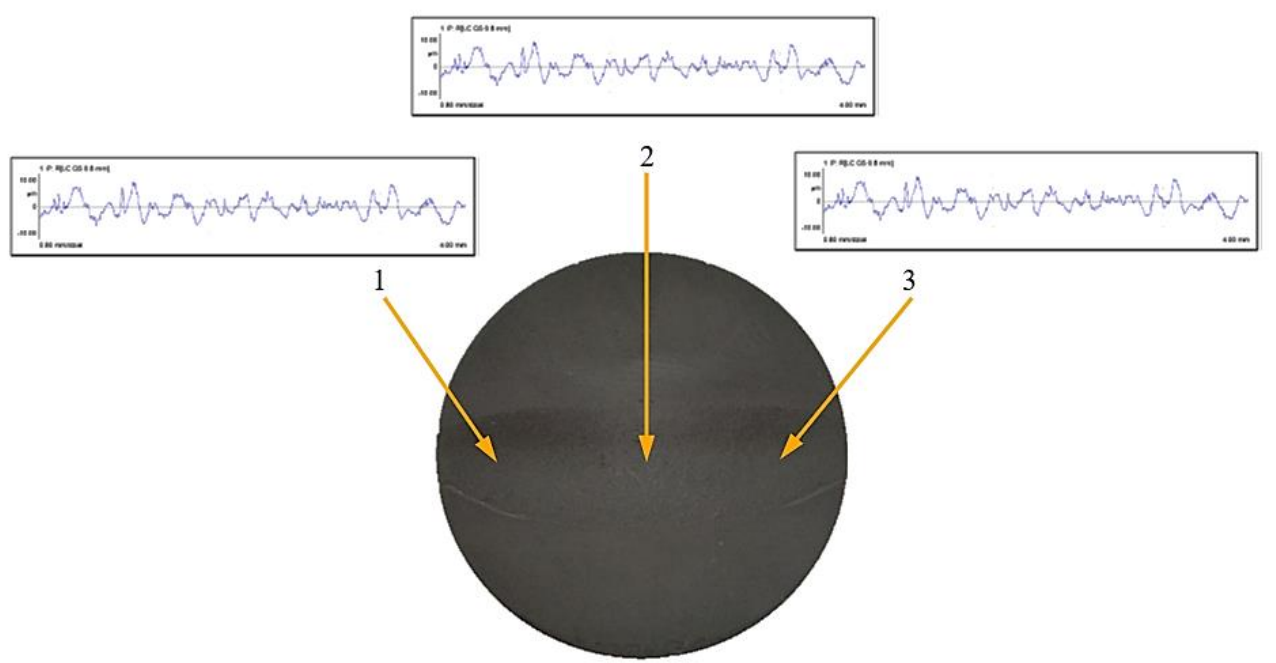

Fig. 6. Places of the coarseness measurement on the studied sample.

\section{Results and their analysis}

The obtained results from the roughness measurements of the studied samples' surfaces are presented in table 1 . In this table there are also presented the results of measurement from individual places of the examined sample and the mean value for the considered samples has been determined. Based on the determined mean roughness values $\mathrm{Ra}$ it has been defines, that the highest quality of the surface's performance with the electrochemical drilling method concerns the samples: 1,6 and 8. In the remaining samples lower quality of the surface's performance was observed.

Table 1. List of the mean values of the measured roughness parameter Ra. 


\begin{tabular}{|l|c|c|c|c|}
\hline & $\begin{array}{c}\text { Place of } \\
\text { measurement } \\
1\end{array}$ & $\begin{array}{c}\text { Place of } \\
\text { measurement } \\
2\end{array}$ & $\begin{array}{c}\text { Place of } \\
\text { measurement } \\
3\end{array}$ & $\begin{array}{c}\text { Mean value } \\
\text { Ra }[\mu \mathrm{m}]\end{array}$ \\
\hline $\begin{array}{l}\text { Sample } \\
1\end{array}$ & 2,38 & 2,76 & 2,09 & 2,41 \\
\hline $\begin{array}{l}\text { Sample } \\
2\end{array}$ & 3,09 & 2,07 & 3,09 & 2,75 \\
\hline $\begin{array}{l}\text { Sample } \\
3\end{array}$ & 2,51 & 2,52 & 3,19 & 2,74 \\
\hline $\begin{array}{l}\text { Sample } \\
4\end{array}$ & 2,78 & 2,63 & 2,89 & 2,77 \\
\hline $\begin{array}{l}\text { Sample } \\
5\end{array}$ & 2,91 & 2,45 & 3,10 & 2,82 \\
\hline $\begin{array}{l}\text { Sample } \\
6\end{array}$ & 2,45 & 2,15 & 2,65 & 2,42 \\
\hline $\begin{array}{l}\text { Sample } \\
7\end{array}$ & 2,65 & 2,55 & 2,79 & 2,66 \\
\hline $\begin{array}{l}\text { Sample } \\
8\end{array}$ & 2,54 & 2,31 & 2,65 & 2,50 \\
\hline $\begin{array}{l}\text { Sample } \\
9\end{array}$ & 2,75 & 2,49 & 2,91 & 2,72 \\
\hline $\begin{array}{l}\text { Sample } \\
10\end{array}$ & 3,02 & 2,61 & 2,81 & 2,81 \\
\hline
\end{tabular}

Having determined the quality of the shaped surfaces in ten samples, subsequently there were analyzed the registered time courses. Analysis of the time courses showed distinct changes in the course of the process of the electrochemical drilling's duration between samples of the highest surface's quality and the samples in the case of which the surface's quality was lower.

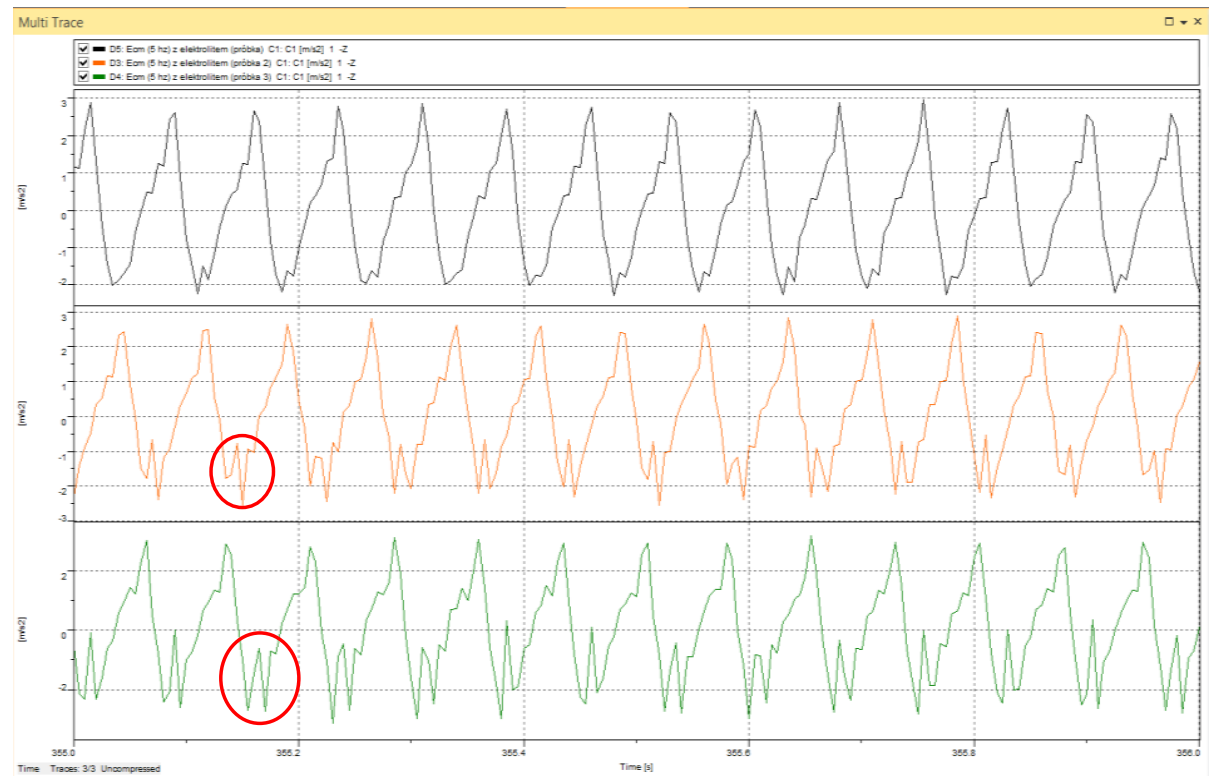

Fig. 7. Presentation of the time courses from the electrochemical drilling process for the sample 1 (black colour), sample 2 (orange colour) and the sample 5 (green colour). 
Analysis of the obtained time courses from the samples representing three different surface's qualities point at a similar impulse character of a high-potential plate in the course of material's machining. However, additionally it was also observed, that in case of the samples in the case of which there occurred a lower quality of the shaped surface, in the time courses there occurred changes of the vibrations' signals in the form marked in figure 7 . These changes occur only in case of samples of low quality of the performed surface, what causes, that this tendency may be identified just with that phenomenon.

The observed effect was tried to be confirmed by making analysis of individual amplitude-frequency courses. The registered forcing frequencies' values, their harmonious and vibrations' amplitudes, are listed in the table 2.

Table 2. List of frequency amplitudes for individual samples subject to electrochemical drilling machining ECM

\begin{tabular}{|c|c|c|c|c|c|c|c|}
\cline { 2 - 9 } \multicolumn{1}{c|}{} & \multicolumn{7}{|c|}{ Amplitude [m/s2] } \\
\hline Frequency [Hz] & 13,48 & 26,95 & 40,43 & 53,91 & 67,58 & 81,05 & 94,53 \\
\hline Sample 1 & 1,37 & 0,66 & 0,26 & 0,12 & 0,11 & 0,18 & 0,03 \\
\hline Sample 2 & 1,34 & 0,33 & 0,20 & 0,11 & 0,07 & 0,14 & 0,04 \\
\hline Sample 3 & 1,37 & 0,43 & 0,37 & 0,16 & 0,21 & 0,26 & 0,12 \\
\hline Sample 4 & 1,32 & 0,56 & 0,23 & 0,10 & 0,08 & 0,18 & 0,02 \\
\hline Sample 5 & 1,28 & 0,47 & 0,28 & 0,13 & 0,07 & 0,17 & 0,11 \\
\hline Sample 6 & 1,38 & 0,62 & 0,28 & 0,14 & 0,09 & 0,22 & 0,04 \\
\hline Sample 7 & 1,35 & 0,65 & 0,31 & 0,13 & 0,10 & 0,17 & 0,01 \\
\hline Sample 8 & 1,36 & 0,60 & 0,27 & 0,18 & 0,15 & 0,18 & 0,02 \\
\hline Sample 9 & 1,33 & 0,57 & 0,39 & 0,15 & 0,20 & 0,23 & 0,13 \\
\hline Sample 10 & 1,31 & 0,54 & 0,33 & 0,12 & 0,03 & 0,22 & 0,13 \\
\hline
\end{tabular}

The values presented in table 2 are also presented in a graphical form in figure 8 .

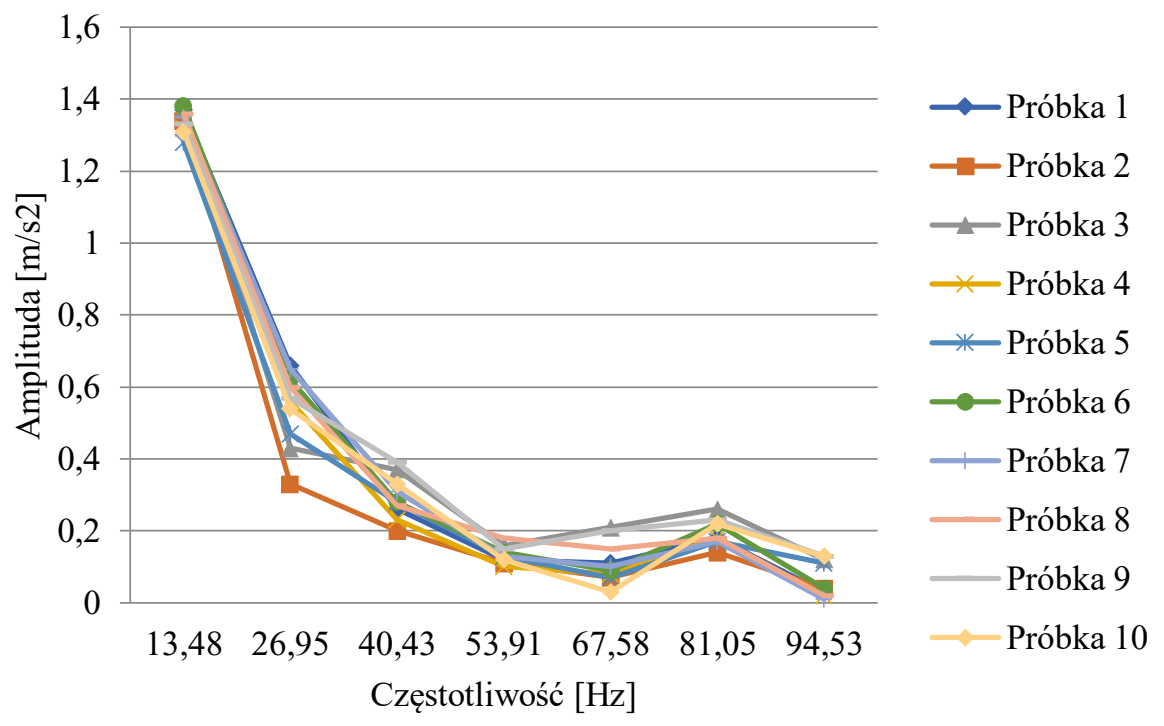

Fig. 8. Diagram of the oscillation amplitudes' values depending on the frequency of the high potential plate's input functions. 
Unfortunately, the analysis of the FFT spectra ambiguously shows, that the quality of the shaped sample's surface may be confirmed based on the analysis of only the values of oscillations' amplitude assigned to forcing frequencies.

\section{Summary}

Dynamic identification of electromechanical machining (ECM) was based on the analysis of the time and frequency courses. The presented results clearly show, that monitoring of such a machining process is better based on the analysis of individual time courses registering the high-potential plate's movement. The changes taking place at the time of the electromechanical drilling process may be observed much better on time courses, what is pointed out in this publication. An individual dependence between the machined surface's quality and the changes in the time characteristics has been observed among the others in these courses' analysis. Additionally, the vibroacoustic analysis has confirmed the assumed high-potential plate vibrations' amplitude obtained with the use of a cam powered with belt transmission. One should have in mind the fact, that the vibroacoustic parameters' values often depend on many sources' operation, of different frequencies and amplitudes. The obtained results of a stand's vibration and the presented time courses' and amplitudefrequency diagrams', are the preliminary results and require further studies.

\section{LITERATURE}

1. S. Zaborowski, Elektrochemiczna intensyfikacja obróbki ściernej materiałów trudno obrabialnych, Prace Instytutu Technologii Maszyn i Automatyzacji Politechniki Wrocławskiej, Monografia, Oficyna Wydawnicza Politechniki Wrocławskiej, Wrocław (2000)

2. P. Frankowski, W. Mielnicki, Kształtowanie elektrochemiczne łopatki sekwencją procesów ECM - PECM, Inżynieria Maszyn, R. 16, (2011)

3. P. G. Pott, Modern electrochemical machining in practice, Proc. ISEM-9, s. 146-150, Nagoya (1989)

4. A. Ruszaj, Application of ECM machining in the Polish industry. Mat. SECM-88, s. 247-283, Lubniewice (1988)

5. L. Dąbrowski, Podstawy komputerowej symulacji kształtowania elektrochemicznego, Pr. Nauk., Mechanika 154, Wyd. Politechniki Warszawskiej, Warszawa (1992)

6. J. Kozak, Kształtowanie powierzchni obróbką elektrochemiczną bezstykową, Pr. Nauk., Mechanika 41, Wyd. Politechniki Warszawskiej, Warszawa (1976)

7. K. Łubkowski, Stany krytyczne w obróbce elektrochemicznej, Pr. Nauk., Mechanika 163, Oficyna Wydawnicza Politechniki Warszawskiej, Warszawa (1996)

8. T. Paczkowski, Symulacja komputerowa obróbki elektrochemicznej powierzchni krzywoliniowych elektrodą roboczą o złożonym ruchu translacyjnym, Wydawnictwo Uczelniane UTP, Bydgoszcz (2012)

9. B. Bhattacharyya, M. Malapati, J. Munda, A. Sarkar, Influence of tool vibration on machining performance in electrochemical micromachining of copper, International J. of Machine Tools \& Manufacture 47, 335-342, Kolkata (2007)

10. M. S. Hewidy, S. J. Ebeid, T. A. El-Taweel, A. H. Youssef, Modelling the performance of ECM assisted by low frequency vibrations, J. of Materials Processing Technology 189, 466-472, Egypt (2007)

11. J. Kozak, Analiza procesu obróbki elektrochemicznej elektrodą drgającą, Mat. konf. EM'97, 204-212, Bydgoszcz - Golub - Dobrzyń (1997) 